\title{
In vivo Analgesic, Anti-hyperglycaemic and CNS Depressant Studies of Commelina paludosa Blume
}

\author{
Mahfuza Afroz Soma ${ }^{1}$, Md. Murad Hasan ${ }^{1}$, Tabassum Jannat ${ }^{1}$ and Md. Abu Sufian ${ }^{2}$ \\ ${ }^{1}$ Department of Pharmacy, State University of Bangladesh, Dhaka-1205, Bangladesh \\ ${ }^{2}$ Marketing Strategy Department, Incepta Pharmaceuticals Ltd., Bangladesh
}

(Received: January 27, 2020; Accepted: June 28, 2020; Published (web): July 25, 2020)

\begin{abstract}
The methanol extract of whole plant of Commelina paludosa Blume (family: Commelinaceae) has been screened to explore its in vivo central and peripheral analgesic, hypoglycaemic and central nervous system depressant activities in Swiss Albino mice. The crude extract significantly increased the latent response time in tail-flick method $(\mathrm{p}<0.001)$ at the doses of 200 and $400 \mathrm{mg} / \mathrm{kg}$ body weight for a 90 minute period when compared to control group. The peripheral analgesic activity was evaluated by acetic acid-induced writhing method and the extract showed significant results $(\mathrm{p}<0.001)$ with 51.72 and $67.24 \%$ inhibition at 200 - and $400-\mathrm{mg} / \mathrm{kg}$ body weight, respectively. In addition, a dose dependant blood glucose lowering and CNS depressant activities were also observed by the crude extract.
\end{abstract}

Key words: Central analgesic activity, peripheral analgesic activity, anti-hyperglycaemic activity, depressant activity

\section{Introduction}

From time immemorial, plants have been used as health care remedies and spread over all around the world populated by human beings. The rich tradition of nature-based interventions to counteract any difficulty or abnormality in daily life has made them a genuine source of reliable and ancient symptomatic remedies. Bangladesh has a profound tradition of medicinal practices. It has more than 5000 floral species, among them around 750 species are generally used in conventional medicines (Pasha et al., 2013; Yousuf et al., 1994; Ghani, 1998).

Commelinaceae family includes 41 genera and 731 species worldwideand is commonly known as the dayflower family or spiderwort family (Christenhusz and Byng, 2016). This ecologically diverse family isusually found in forests and grasslands (Kubitzia, 1998). Commelina paludosa Blume (Bengali name: Batboittashak/Kanshira/Kannyalata; English name: Dayflower) belonging to the Commelinaceae family, is a perennial herb up to $45-60 \mathrm{~cm}$ in height with largest leaves and petals among taxa of Commelina (Gajurel and Shrestha, 2009). It is widely distributed in Bangladesh, India, Sri Lanka, Pakistan, Malaysia, Indonesia and the Philippines (Nordal, 1963).The boiled leaves mixed with crushed peppers are taken orally 2-3times a day to treat dysentery by the Chakma tribes of Rangamati district in Bangladesh (Rahmatullah et al., 2011; Rahmanet al., 2007). The people of Tripura rub small blue flowers on the body during itching (Majumdar and Datta, 2007). The root is used to treat vertigo, fevers, and bilious afflictions (Nordal, 1963). In 2018, Riaz et al. postulated that the whole plant possessed significant antioxidant, antibacterial, antidiarrheal as well as antipyretic activity in the in vitro and in vivo test systems.

A quick literature survey revealed little pharmacological studies with this plant, and we herein, report the results of our preliminary pharmacological investigation. 


\section{Materials and Methods}

Collection of plant materials and extraction: The whole plants of $C$. paludosa were collected from Chittagong. The plant was identified in Bangladesh National Herbarium, Dhaka, Bangladesh where a voucher specimen (Accession no. DACB-48274) has been perpetuated for future reference.

The collected plant materials were cleaned, sun dried and powdered using a grinding machine. The ground material $(500 \mathrm{~g})$ was soaked in 2.5 litre of methanol in an amber glass bottle at room temperature for almost 15 days. The mixture was filtered through a piece of clean cotton and then filtered with Whatman filter paper number 1 . The filtrate was evaporated with a rotary evaporator and a dense gummy mass was obtained which was known as crude methanol extract. This extract was transferred to a clean beaker and preserved in refrigerator for further experiments.

Drugs and chemicals: Methanol, castor oil, glucose, Tween-80 (BDH Chemicals, UK), normal saline solution (Beximco Infusion Ltd. Bangladesh), Morphine (Gonoshastho Pharmaceuticals Ltd., Bangladesh), diclofenac sodium, glibenclamide and diazepam (Square Pharmaceuticals Ltd., Bangladesh) were used in the present study. All other reagents were of analytical grade.

Experimental animals: Swiss Albino mice of both sexes (weighing between 25-35 gm) and 4-5 weeks old were taken for the experiments. The mice were kept in the animal house of State University of Bangladesh under standard environmental condition (at $24.0 \pm 1{ }^{\circ} \mathrm{C}$ and $55-65 \%$ relative humidity and 12 hrs light/12 hrs dark cycle) and fed with rodent feed collected from the icddr,b and water ad libitum. The animals were acclimatized for a week in the laboratory environment prior to use for the experiments. The Federation of European Laboratory Animal Science Associations (FELASA) guidelines and recommendations were followed to reduce the pain and stress of the experimental mice.

Grouping of mice: Twenty Swiss Albino mice were randomly divided into four groups having five animals in each group for each bioassay: positive control (STD), negative control (CTL) and two test groups receiving methanolic extract at doses of 200(CP 200) and 400(CP 400) mg/kg of body weight.

Central analgesic activity: The central analgesic activity was investigated by tail flicking method (Pizziketti et al., 1985). Two doses were fed orally to the mice and the tips of their tail were immersed in hot water which acted as pain stimulus. The reaction time required by the mice to deflect their tails was termed as tail immersion time which was recorded at 30, 60 and 90minutes after the administration of the extract or drug. The positive control group received morphine (2-mg/kg b.w.) subcutaneously and the negative control group was given $1 \%$ Tween 80 in saline mixture $(0.1 \mathrm{~mL} / 10 \mathrm{mg})$ orally. The pain inhibition percentage (PIP) was calculated using the following formula:

Pain inhibition percentage $(\mathrm{PIP})=\left[\frac{T_{1}-T_{0}}{T_{0}}\right] \times 100$ where, $T_{1}=$ Post-drug latency and $T_{0}=$ Pre-drug latency

Peripheral analgesic activity: The acetic acidinduced writhing method was followed to evaluate peripheral analgesic activity as described by Koster et al. (1959). In this method, pain sensation was induced by administering $0.1 \mathrm{~mL}$ of acetic acid to the experimental animals intraperitoneally. Diclofenac sodium (5-mg/kg b.w.) was given intraperitoneally to the positive control group. In the experimental groups, the crude extract was used for the evaluation of analgesic activity at 200 -and $400-\mathrm{mg} / \mathrm{kg}$ of b.w. and the percentage of writhing inhibition was calculated by using the following equation:

$$
\text { Percentage inhibition }=\frac{\text { Control licking response }- \text { Test licking response }}{\text { Control licking response }} \times 100 \%
$$

Anti-hyperglycaemic activity: The antihyperglycaemicactivityof the test samples was assessed by following the tail tipping method described by Durschlag et al. (1996), where the lowering of blood glucose level of the experimental animals was measured. The control group received 
$1 \%$ Tween 80 in normal saline $(10 \mathrm{ml} / \mathrm{kg}$ body weight), the standard group received glibenclamide (5-mg/kg b.w.) and the experimental groups were fed with crude extract of $200-$ and $400-\mathrm{mg} / \mathrm{kg}$ b.w. The blood glucose level $(\mathrm{mmol} / \mathrm{L})$ of the experimental animals was measured at zero minute using a glucometer (Bioland G-423 S). Then the control, standard and methanolic crude extract (200- and 400$\mathrm{mg} / \mathrm{kg}$ b.w.) were administered orally to the experimental animals with the help of feeding needle. After 30 minutes, all groups were treated with $10 \%$ glucose solution $(2-\mathrm{g} / \mathrm{kg}$ b.w.). Then 60,120 and 180minafter glucose loading, blood samples were collected from tail vein. By using glucometer, the blood glucose level of the experimental animals was measured to observe the anti-hyperglycaemic effect of the crude methanol extract of $C$. paludosa with respect to control and standard groups.

Determination of CNS depressant activity by open field test: The experiment was carried out according to the method described by Zhao et al.(1992). The floor of an open field was divided into alternatively colored black and white squares and the wall height was $40 \mathrm{~cm}$. The negative control, positive controland test group received $1 \%$ Tween 80 in water, diazepam (1-mg/kg b.w., p.o.) andmethanol extract (200- and 400-mg/kg b.w.), respectively. After giving test drugs, the number of animal movements was counted up to $3 \mathrm{~min}$ at $0,30,60,90$ and $120 \mathrm{~min}$.

Determination of CNS depressant activity by hole cross test: The hole cross test was conducted to determine the sedative activity of the plant following the method explained by Takagi et al. (1971). A specific type of cage is used in this method which consists of a steel partition fixed in the middle of the cage having a size of $30 \times 20 \times 14 \mathrm{~cm}$. In the center of the cage, a hole of $3 \mathrm{~cm}$ diameter was made at a height of $7.5 \mathrm{~cm}$. Control mice received vehicle (1\% Tween 80 in water), positive control received diazepam (1-mg/kg b.w., p.o.) and the experimental animals received methanol extract (200- and 400$\mathrm{mg} / \mathrm{kg}$ b.w.) of C. Paludosa, respectively. After oral administration of test drugs, the number of passages of mice through the hole from one chamber to other was calculated for a period of $3 \mathrm{~min}$ at $0,30,60,90$ and $120 \mathrm{~min}$.

Statistical analysis: The values are presented as mean \pm standard error of mean $(\mathrm{M} \pm \mathrm{SEM})$ and One way ANOVA followed by Dunnett's test were used to determine the significance difference between the control group and experimental groups, the $\mathrm{p}$ values < 0.05 were considered to be statistically significant.

\section{Results and Discussion}

The central analgesic effects of methanolic extract of the whole plant of $C$. paludosa in the tail flicking method are shown in table 1 . The extract increased the response time at both the doses (200and $400-\mathrm{mg} / \mathrm{kg}$ b.w.) by 63.37 and $77.17 \%$, respectively in the first 30 mins as compared to the standard, morphine $(86.75 \%)$. The percent of elongation of flicking response kept on increasing in a dose and time dependent manner. Even though in every case the values for the two doses of the sample were lower compared to morphine, the data were found to be statistically significant. In the present study, central analgesic activity was evaluated by using the tail flick method which is considered to be a spinal reflex induced by heat according to Pizziketti et al. (1985). But it could also involve higher neural structures (central analgesic activity). Pain is centrally regulated via a number of complex processes which include opiate, dopaminergic descending noradrenergic and serotonergic systems (Mishra et al., 2011). C. paludosa produced significant increase in pain threshold at both the doses in tail flick model. The analgesic effect produced by the doses of test samples and standard may be acting through central mechanisms involving these receptor systems or via peripheral mechanisms involved in the inhibition of prostaglandins, leukotrienes and other endogenous substances that are key mediators in pain.

The peripheral analgesic activity exhibited by the plant extract in acetic acid-induced writhing method is presented in table 2. The number of abdominal muscle contraction induced by $0.1 \mathrm{ml}$ of acetic acid was effectively reduced by the extract in a dose dependant manner. Statistical evaluation of the data 
confirmed that the crude extract of whole plant of $C$. paludosa demonstrated significant peripheral analgesic activity having writhing inhibition of 50.00 and $62.22 \%$ at $200-$ and $400-\mathrm{mg} / \mathrm{kg}$ of b.w., respectively when compared to that of the standard diclofenac sodium (72.22\% inhibition). Acetic acidinduced writhing test was done to evaluate the peripheral analgesic activity of C. paludosa in mice according to the method of Koster et al. (1959). In this test, pain is induced in peripheral origin by injection of irritant principles such as acetic acid in mice. The writhing response is considered as a reflexive test which is highly useful for screening analgesic drugs (Gawade, 2012). Acetic acid generates pain through the activation of chemosensitive nociceptors or irritation of the visceral surface, which lead to the liberation of endogenous substances such as serotonin, histamine, prostaglandins, bradykinins (Schumacher et al., 1940). Local peritoneal receptors are presumed to be involved in the abdominal constriction response (Bentley et al., 1983). The reduction of the writhing frequency or abdominal constrictions deduces the analgesic activity of the test compound. Intraperitoneal injection of acetic acid produced abdominal writhing in this study. The extracts derived from $C$. paludosa whole plant exhibited significant analgesic activity in Swiss Albino mice by inhibiting acetic acid induced writhing. Therefore, the extract might be inhibiting synthesis or release of these endogenous substances.

Table 1. Central analgesic activity of crude methanol extract of $C$. paludosa whole plant.

\begin{tabular}{|c|c|c|c|c|c|c|}
\hline \multirow{2}{*}{$\begin{array}{l}\text { Animal } \\
\text { group }\end{array}$} & \multicolumn{2}{|c|}{ After $30 \mathrm{~min}$} & \multicolumn{2}{|c|}{ After $60 \mathrm{~min}$} & \multicolumn{2}{|c|}{ After $90 \mathrm{~min}$} \\
\hline & $\mathrm{M} \pm \mathrm{SEM}$ & $\%$ Elongation & $\mathrm{M} \pm \mathrm{SEM}$ & $\%$ Elongation & $\mathrm{M} \pm \mathrm{SEM}$ & $\%$ Elongation \\
\hline CTL & $2.32 \pm 0.08 *$ & - & $2.35 \pm 0.19^{*}$ & - & $2.21 \pm 0.06^{*}$ & - \\
\hline STD & $4.34 \pm 0.13 *$ & 86.75 & $8.35 \pm 0.04 *$ & 255.32 & $12.81 \pm 0.16^{*}$ & 478.86 \\
\hline CP 200 & $3.80 \pm 0.13 *$ & 63.37 & $5.53 \pm 0.08 *$ & 135.40 & $7.11 \pm 0.18^{*}$ & 221.36 \\
\hline CP 400 & $4.12 \pm 0.13^{*}$ & 77.17 & $6.22 \pm 0.25^{*}$ & 164.79 & $8.10 \pm 0.18^{*}$ & 265.93 \\
\hline
\end{tabular}

Values are expressed as Mean \pm SEM $(n=5) .{ }^{*} \mathrm{p}<0.001$ compared to negative control. CTL $=$ negative control $(1 \%$ Tween 80 in water), STD = positive control (Morphine at $2-\mathrm{mg} / \mathrm{kg}$ b.w.), CP $200=$ Methanolic extract of C. paludosa whole plant at 200-mg/kg b.w., CP $400=$ Methanolic extract of $C$. paludosa whole plant at $400-\mathrm{mg} / \mathrm{kg}$ b.w.

Table 2. Peripheral analgesic activity of crude methanol extract of $C$. paludosa whole plant.

\begin{tabular}{|c|c|c|c|c|c|c|c|}
\hline \multirow{2}{*}{$\begin{array}{l}\text { Animal } \\
\text { group }\end{array}$} & \multicolumn{5}{|c|}{ Writhing count (sec) } & \multirow{2}{*}{$\begin{array}{l}\text { Number of writhing } \\
\text { (Mean } \pm \text { SEM })\end{array}$} & \multirow{2}{*}{$\begin{array}{l}\% \text { Inhibition of } \\
\text { writhing }\end{array}$} \\
\hline & M-1 & M-2 & M-3 & M-4 & M-5 & & \\
\hline CTL & 19 & 18 & 16 & 17 & 20 & $18.00 \pm 0.71 *$ & - \\
\hline STD & 7 & 4 & 4 & 4 & 6 & $5.00 \pm 0.63^{*}$ & 72.22 \\
\hline CP 200 & 9 & 11 & 8 & 7 & 10 & $9.00 \pm 0.71^{*}$ & 50.00 \\
\hline CP 400 & 5 & 6 & 10 & 6 & 7 & $6.80 \pm 0.86^{*}$ & 62.22 \\
\hline
\end{tabular}

Values are expressed as Mean \pm SEM $(n=5)$. * $p<0.001$ compared to negative control. CTL $=$ negative control $(1 \%$ Tween 80 in water), STD = positive control (Diclofenac sodium at $5 \mathrm{mg} / \mathrm{kg}$ body weight). M1, M2, M3, M4, M5 = Mice 1, Mice 2, Mice 3, Mice 4, Mice 5, respectively.

The extract of $C$. paludosa when administered orally at $200-$ and $400-\mathrm{mg} / \mathrm{kg}$ b.w. did not exhibit significant glucose lowering effect when compared to control. However, the percent reduction of blood glucose level was found to be dose dependant. In this study, maximum effect was observed at the dose of 400-mg/kg b.w. (Table 3). Various studies revealed thatplant extracts exert anti-hyperglycaemic effect by stimulating or regenerating $\beta$ cells or by protecting these cells from destruction, by restricting glucose load as well as by inducing unrestricted endogenous insulin action (Josephet al., 2011). Anti- 
hyperglycaemic effect may also be caused by insulin release from $\beta$ cells or activation of the insulin receptors to absorb the blood sugar and stimulate the peripheral glucose consumption by plant extract (Khan et al., 2014). In the present study, the crude methanolic extract of $C$. paludosa produced nonsignificant hypoglycemic effect on experimental mice. However, the percentage reduction of blood glucoseof the whole plant extract was comparable with the standard drug.
During evaluation of CNS depressant activity by the open field and hole cross test, crude extract of $C$. paludosa at both the doses showed dose dependent sedative effects in comparison to the standard drug (diazepam) (Table 4 and Table 5). There was no statistically significant difference among the values of control and the two dosages in both the experiments. Increased alertness indicates increase in locomotor activity whereas decrease in locomotor activity indicates sedative effect (Crunkhorn et al., 1971).

Table 3. Anti-hyperglycaemic activity of methanol extract of C. paludosa.

\begin{tabular}{ccccccc}
\hline $\begin{array}{c}\text { Animal } \\
\text { group }\end{array}$ & Dose & $\begin{array}{c}0 \mathrm{~min} \\
\mathrm{M} \pm \mathrm{SEM} \\
(\mathrm{mmol} / \mathrm{l})\end{array}$ & $\begin{array}{c}30 \mathrm{~min} \\
\mathrm{M} \pm \mathrm{SEM} \\
(\mathrm{mmol} / \mathrm{l})\end{array}$ & $\begin{array}{c}60 \mathrm{~min} \\
\mathrm{M} \pm \mathrm{SEM} \\
(\mathrm{mmol} / \mathrm{l})\end{array}$ & $\begin{array}{c}120 \mathrm{~min} \\
\mathrm{M} \pm \mathrm{SEM} \\
(\mathrm{mmol} / \mathrm{l})\end{array}$ & $\begin{array}{c}180 \mathrm{~min} \\
\mathrm{M} \pm \mathrm{SEM} \\
(\mathrm{mmol} / \mathrm{l})\end{array}$ \\
\hline CTL & - & $5.20 \pm 0.59$ & $23.22 \pm 4.47$ & $19.36 \pm 4.30$ & $7.22 \pm 0.45$ & $4.18 \pm 0.47$ \\
STD & $5-\mathrm{mg} / \mathrm{kg}$ b.w. & $5.20 \pm 0.35$ & $16.32 \pm 1.21$ & $11.82 \pm 1.27$ & $4.50 \pm 0.69$ & $2.90 \pm 0.31$ \\
CP 200 & 200-mg/kg b.w. & $4.66 \pm 0.59$ & $14.18 \pm 1.33$ & $10.08 \pm 1.32$ & $6.48 \pm 0.50$ & $4.50 \pm 0.18$ \\
CP 400 & 400-mg/kg b.w. & $5.06 \pm 0.32$ & $18.98 \pm 0.64$ & $11.58 \pm 1.87$ & $7.80 \pm 1.42$ & $4.78 \pm 0.57$ \\
\hline
\end{tabular}

Values are expressed as Mean $\pm \operatorname{SEM}(n=5)$. CTL $=$ negative control $(1 \%$ Tween 80 in water $)$ STD = positive control (Glibenclamide at 5-mg/kg b.w.).

Table 4. Depressant effects of the methanol extract of $C$. paludosa whole plant on open field test in mice model.

\begin{tabular}{lcccccc}
\hline \multirow{2}{*}{$\begin{array}{l}\text { Animal } \\
\text { group }\end{array}$} & Dose & \multicolumn{5}{c}{ Number of movements (Mean \pm SEM) } \\
\cline { 3 - 6 } & & $0 \mathrm{~min}$ & $30 \mathrm{~min}$ & $60 \mathrm{~min}$ & $90 \mathrm{~min}$ & $120 \mathrm{~min}$ \\
\hline CTL & - & $184.20 \pm 25.12$ & $102.00 \pm 35.43$ & $43.00 \pm 14.32$ & $102.00 \pm 12.45$ & $40.00 \pm 14.58$ \\
STD & $1-\mathrm{mg} / \mathrm{kg}$ & $89.00 \pm 1.69^{* *}$ & $87.40 \pm 0.91$ & $70.00 \pm 1.84$ & $65.00 \pm 1.58^{*}$ & $51.00 \pm 1.77$ \\
CP 200 & $200-\mathrm{mg} / \mathrm{kg}$ b.w. & $212.00 \pm 20.43$ & $100.00 \pm 25.74$ & $72.00 \pm 16.36$ & $56.00 \pm 22.53$ & $52.00 \pm 20.74$ \\
CP 400 & $400-\mathrm{mg} / \mathrm{kg}$ b.w. & $177.00 \pm 30.70$ & $90.00 \pm 25.00$ & $84.00 \pm 11.51^{*}$ & $48.00 \pm 17.10^{*}$ & $26.00 \pm 9.75$ \\
\hline
\end{tabular}

Values are expressed as Mean $\pm \operatorname{SEM}(\mathrm{n}=5) . * \mathrm{p}<0.001, * * \mathrm{p}<0.01$ compared to control. CTL $=$ negative control $(1 \%$ Tween 80 in water), STD = Positive control (Diazepam at $1-\mathrm{mg} / \mathrm{kg} \mathrm{b.w.).}$

Table 5. Depressant effects of the methanol extract of $C$. paludosa whole plant on hole cross test in mice.

\begin{tabular}{lcccccc}
\hline \multirow{2}{*}{$\begin{array}{l}\text { Animal } \\
\text { group }\end{array}$} & Dose & \multicolumn{5}{c}{ Number of movements (Mean \pm SEM) } \\
\cline { 3 - 7 } & & $0 \mathrm{~min}$ & $30 \mathrm{~min}$ & $60 \mathrm{~min}$ & $90 \mathrm{~min}$ & $120 \mathrm{~min}$ \\
\hline CTL & - & $2.40 \pm 1.35$ & $3.40 \pm 1.85$ & $2.20 \pm 1.64$ & $1.60 \pm 1.23$ & $4.40 \pm 1.62$ \\
STD & $1-\mathrm{mg} / \mathrm{kg}$ & $6.60 \pm 1.07 * *$ & $5.40 \pm 1.07$ & $3.80 \pm 0.92$ & $3.80 \pm 1.47$ & $3.00 \pm 1.26$ \\
CP 200 & $200-\mathrm{mg} / \mathrm{kg}$ b.w. & $3.20 \pm 2.25$ & $2.60 \pm 1.89$ & $2.20 \pm 1.39$ & $2.40 \pm 1.44$ & $1.20 \pm 1.05$ \\
CP 400 & $400-\mathrm{mg} / \mathrm{kg}$ b.w. & $4.40 \pm 2.17$ & $2.40 \pm 1.40$ & $1.40 \pm 1.23$ & $1.00 \pm 1.12$ & $0.60 \pm 0.74$ \\
\hline
\end{tabular}

Values are expressed as Mean \pm SEM $(n=5) . * * p<0.01$ compared to control. CTL $=$ negative control $(1 \%$ Tween 80 in water), STD = Positive control (Diazepam at $1-\mathrm{mg} / \mathrm{kg}$ b.w.).

Sedative-hypnotic, anxiolytic and muscle relaxant drugs revealed their activity through the inhibition of gamma-aminobutyric acid (GABA) which is the major inhibitory neurotransmitter. Open field and hole cross methods are common ways to investigate the depressant activity of crude extracts. In this study, 
the methanol extract of $C$. paludosa showed dose dependant depressant activity which might be due to the direct activation of GABA receptor enhancing GABAergic inhibition in the CNS.

\section{Conclusion}

The whole plant extract of $C$. paludosa was found to be effective in analgesic, hypoglycemic and depressantactivities. Therefore, further studies are needed to discover other bioactivities.

\section{References}

Bentley, G.A., Newton, S.H. and Starr, J. 1983. Studies on the antinociceptive action of alpha-agonist drugs and their interactions with opioid mechanisms. $\mathrm{Br} J$ Pharmacol.79, 125-34.

Christenhusz, M.J.M. and Byng, J.W. 2016. The number of known plants species in the world and its annual increase. Phytotaxa, 261, 201-217.

Crunkhorn, P. and Meacock, S.C.R. 1971. Mediators of the inflammation induced in the rat paw by carrageenin. Br. J. Pharmacol. 42, 392-402.

Durschlag, M., Wurbel, H., Stauffacher, M. and Holst, D.V. 1996. Repeated blood collection in the laboratory mouse by tail incision-modification of an old technique. Physiol. Behav. 60, 1565-1568.

Gajurel, J.P. and Shrestha, K.K. 2009.Taxonomy of the genus Commelina Plum.ex L. (Commelinaceae) in Nepal. Botanica Orientalis: J. Plant Sci. 6, 25-31.

Gawade, S.P. 2012. Acetic acid induced painful endogenous infliction in writhing test on mice. J. Pharmacol. Pharmacother. 3, 348.

Ghani, A. 1998. Medicinal Plants of Bangladesh: Chemical Constituents and Uses. Asiatic Society of Bangladesh, pp.1-33.

Joseph, B. and Jini, D. 2011. Insight into the hypoglycaemic effect of traditional Indian herbs used in the treatment of diabetes. Res. J. Med. Plant, 5, 352-376.

Khan, M.F., Khan, Z.I., Uddin, M.R, Rahman, M.S., and Rashid, M.A. 2014.In vivo hypoglycemic and alloxan induced antidiabetic activity of Xeromphis uligonosa Retz. Afr. J. Pharm. Pharmacol. 9, 363-366.

Koster, R., Anderson, M. and De Beer, E.J. 1959.Acetic acid for analgesic screening. Proc. Soc. Exp. Biol. Med. 18, 412-415.

Kubitzia, K. 1998. The Families and Genera of Vascular Plants. Springer, New York, USA.
Majumdar, K. and Datta, B.K. 2007. A study on ethnomedicinal usage of plants among the folklore herbalists and Tripuri medical practitioners: Part-II. Nat. Prod. Radiance. 6, 66-73.

Mishra, D., Ghosh, G., Kumar, P.S. and Panda, P.K. 2011.An experimental study of analgesic activity of selective COX-2 inhibitor with conventional NSAIDs. Asian J. Pharm. Clin. Res. 4, 78-81.

Nordal, A. 1963. The Medicinal Plants and Crude Drugs of Burma. Hellstrom \& Nordahls Boktrykkeri, Oslo.

Pasha, M.K. and Uddin, S.B. 2013.Dictionary of Plant Names of Bangladesh. Janokalyan Prokashani, Chittagong, Bangladesh, pp. 1-434.

Pizziketti, R.J., Pressman, N.S., Geller, E.B., Cowan, A. and Adler, M.W. 1985. Rat cold water tail-flick: a novel analgesic test that distinguishes opioid agonists from mixed agonist-antagonists. Eur. J. Pharmacol. 119, 23-29.

Rahman, M.A., Uddin, S.B. and Wilcock, C.C. 2007. Medicinal plants used by Chakma tribe in hill districts of Bangladesh. Indian J. Trad. Know. 6, 508-517.

Rahmatullah, M., Chakma, P., Paul, A.K., Nasrin, D., Ahmed, R., Jamal, F., Ferdausi, D., Akber, M., Nahar, N., Ahsan, S. and Jahan, R. 2011.A survey of preventive medicinal plants used by the Chakma residents of Hatimara (south) village of Rangamati district, Bangladesh. Am.-Eurasian J. Sustain. Agric. 5, 92-96.

Riaz, T.A., Hossain, S., Ferdous, J., Hossain, M., Islam, M.T., Chae, H.J. and Hossain, M.K., 2018. Antioxidant, antibacterial, antidiarrheal and antipyretic activities of organic crude fractions of Commelina paludosa. Ayu.39, 101-106.

Schumacher, G.A., Goodell, H., Hardy, J.D. and Wolff, H.G. 1940. Uniformity of the pain threshold in man. Science. 92, 110-2.

Takagi, K., Watanabe, M. and Saito, H. 1971. Studies on the spontaneous movement of animals by the Hole cross test: Effect of 2-dimethylami-noethane. Its acylates on the central nervous system. Jpn. J. Pharmacol. 21, 797-810.

Yusuf, M., Chowdhury, J.U., Wahab, M.A. and Begum, J. 1994. Medicinal Plants of Bangladesh. Bangladesh Council of Scientific and Industrial Research, Dhaka1205, Bangladesh.

Zhao, G.X., Hui, Y., Rupprecht, J.K., McLaughlin, J.L. and Wood, K.V. 1992. Additional bioactive compounds and trilobacin, a novel highly cytotoxic acetogenin, from the bark of Asimina triloba. J. Nat. Prod. 55, 347-56. 